Article

\title{
From Co-Management to Landscape Governance: Whither Ghana's Modified Taungya System?
}

\author{
Mirjam A. F. Ros-Tonen ${ }^{1, *}$, Mercy Derkyi ${ }^{2}$ and Thomas F. G. Insaidoo ${ }^{3}$ \\ 1 Department of Geography, Planning and International Development Studies, \\ University of Amsterdam, P.O. Box 15629, 1001 NC Amsterdam, The Netherlands \\ 2 Department of Forest Science, School of Natural Resources, The University of Energy and Natural \\ Resources (UENR), P.O. Box 214, Sunyani, Brong Ahafo Region, Ghana; \\ E-Mail: mercy.derkyi@uenr.edu.gh or afuaderkyi@yahoo.com \\ 3 Faculty of Renewable Natural Resources (FRNR), Kwame Nkrumah University of Science and \\ Technology (KNUST), Kumasi, Ashanti Region, Ghana; E-Mail: tfginsaidoo@gmail.com \\ * Author to whom correspondence should be addressed; E-Mail: m.a.f.ros-tonen@uva.nl; \\ Tel.: +31-20-525-4179; Fax: +31-20-525-4051.
}

External Editors: Pablo Pacheco and George Schoneveld

Received: 28 October 2014; in revised form: 14 November 2014 / Accepted: 27 November 2014 / Published: 4 December 2014

\begin{abstract}
Natural resource management literature has documented three paradigm shifts over the past decade: from co-management to adaptive co-management and adaptive governance respectively and, more recently, towards landscape governance. The latter is conceived as a governance approach towards negotiated land use at the landscape level to deal with global challenges such as food insecurity, climate change and biodiversity loss. There is not a lot of clarity about how co-management systems could actually evolve into landscape governance. This paper aims to address the gap by exploring how a stalled co-management system for the reforestation of degraded forest areas - the modified taungya system (MTS) in Ghana - could be revitalised and redesigned as a landscape approach. Drawing on case studies and expert consultation, the performance of the national MTS and the MTS under the Community Forestry Management Project is reviewed with regard to five principles (integrated approach, multi-stakeholder negotiation, polycentric governance, continual learning and adaptive capacity) and three enabling conditions (social capital, bridging organisations and long-term funding) distilled from the literature. The authors conclude that some of these principles and conditions were met under the
\end{abstract}


Community Forestry Management Project, but that continual learning, transcending jurisdictional boundaries, developing adaptive capacity, and long-term funding and benefits still pose challenges.

Keywords: adaptive co-management; adaptive governance; landscape governance; landscape approach; social capital; bridging organisations; reforestation; modified taungya system; Ghana

\section{Introduction}

Literature on co-management-defined as the sharing between the state and user groups of responsibilities and decision-making power over certain resources in a particular area [1] —has exhibited two paradigm shifts over the past decade. The first was from co-management to adaptive co-management to deal with dynamics and complexities of socio-ecological systems [2-5]. The second shift was from adaptive co-management to adaptive (multi-level) governance [4,6-8] to deal with a greater variety of public and private actors and environmental problems that transcend the local scale such as climate change. In the literature, the evolution from co-management to adaptive governance presents itself more as a continuum with blurring boundaries between co-management, adaptive co-management and adaptive governance. Several authors [4,9-12] wrote about co-management as an adaptive social learning and negotiation process, while Armitage et al. [13] referred to adaptive co-management as multi-level governance. Parallel and specifically related (but not limited) to forest resources, a third paradigm shift can be observed towards landscape governance [14-16]. The latter is a multi-sector, multi-actor and multi-level governance approach [16] towards negotiated land use at the landscape level that inherently integrates the principles of adaptive and multi-level governance to deal with global challenges such as food insecurity, climate change and biodiversity loss [15,17]. Although integrated landscape approaches have a longer history, e.g., as integrated watershed management programmes since the mid-20th century, landscape governance is still largely experimental [16]. Although in the current debates "landscape approach" is often used in the sense of a governance approach, we try to avoid confusion in this paper by using "landscape approach" as a general denominator for tools and concepts underlying multi-stakeholder approaches and analyses at the landscape level [15,18], and "landscape governance" to refer to the actual multi-sector and multi-actor interactions at landscape level aimed at "solving societal problems and creating societal opportunities" [19] (p.17).

Whereas a lot of literature sheds light on the practice and performance of adaptive co-management [20,21], the role of social learning and bridging organisations in adaptive management [1,22], and the principles for multilevel adaptive governance [4,23,24] and landscape governance [15], there is little clarity about how co-management systems could actually evolve into a landscape approach and landscape governance.

This paper seeks to address this gap by using the case of the modified taungya system (MTS) in Ghana to explain how a co-management system runs into a deadlock if it fails to evolve into adaptive governance and take landscape dynamics into account. At the same time, we aim to explore how the 
MTS could be redesigned as a landscape approach that is governed by principles of adaptive, negotiated and multilevel governance.

The MTS has been designed and implemented since 2002 as a co-management system between the Ghana Forestry Commission and local communities for the reforestation of degraded forest reserves with timber trees, in which participating farmers could interplant food crops and receive $40 \%$ of timber benefits in return for their input in tree planting and maintenance [25-30]. It differed from the traditional taungya system implemented in Ghana between 1930 and 1984 in that farmers gained a right to share in the timber revenues as well as decision-making power in the management of the scheme.

In 2010, the establishment of new MTS plots was suspended to make place for an institutional partnership between the Forestry Commission, District Assemblies and Stools (constitutionally any person or body of persons with control over community land as a representative of a particular community) [31]. This arrangement excluded farmers and communities and reduced their role to workers to be hired for tree planting and maintenance, whereby the focus was on the youth [28]. A lack of financial means to pay for the labour soon put an end to this scheme and led to discussions in Ghana about reactivating the MTS [32]. This article aims to explore how this can be done in a way that leads to adaptive and multilevel landscape governance. Social and environmental dynamics inherent in social-ecological systems call for "climate smart" [33,34] multifunctional landscapes and for institutional arrangements that steer them in an integrated and adaptive manner. We argue that a revitalised and redesigned MTS based on hybrid actor arrangements can play a role in achieving integrated landscape governance and provide food, commodities (timber) and environmental services, such as carbon sequestration $[35,36]$. There are, however, no easy answers to the question of how the MTS should be redesigned to that end, as landscapes approaches are still more of a set of principles than established practice with clearly defined institutional arrangements [37-40]. Based on lessons learned from earlier research on the MTS and a literature review of trends in natural resource governance, this paper addresses the question: whither the MTS? Is it time for a next phase that follows the paradigm shifts in natural resource governance? And if so, what should it look like and how can this transformation into adaptive and multilevel landscape governance best be achieved? Based on the authors' cumulative insights gained from previous research on the scheme [27-30] we review the performance of the MTS in relation to five principles and three conditions for adaptive landscape governance drawn from landscape [15] and adaptive co-management literature [4,12,22-24]. In this way we hope to explain the reasons for the systems' deadlock and outline the way forward. It should thereby be noted that landscape governance is adaptive by definition as it aims to cope with non-linear change, shocks and unforeseen disturbances that are intrinsic in landscapes. This is captured in the principle of "continual learning and adaptive management" [15]. Although this means that "adaptive landscape governance" is in fact a tautology, we still use the term to emphasise our aim to integrate ideas about adaptive and landscape governance as a new way forward for the MTS.

The paper is structured as follows. The next section elaborates on the methodology for this study, clarifying the principles used in the analysis and the source of data. Next, the performance of the MTS is analysed using the principles and enabling conditions for adaptive landscape governance. In the discussion we relate the findings to the current deadlock of the MTS and discuss the way forward, connecting to recent debates on natural resource and landscape governance. 


\section{Methods}

\subsection{Principles of Adaptive Landscape Governance}

Principles and preconditions for adaptive co-management, adaptive governance and landscape approaches and governance have been reviewed (Table 1) and synthesised below as a basis for analysing the potential of the MTS to evolve into adaptive landscape governance. We grouped the principles in five categories (Table 2) and focus on three enabling factors (Table 3).

\subsubsection{Integrated Approach}

Both adaptive and landscape governance emphasise the need for integrated approaches that see landscapes as social ecological systems (SES) in which humans and ecosystems are intrinsically linked [4]. These SES are to be governed in order to increase resilience, which is defined as "the capacity of a system to absorb disturbance and reorganise while undergoing change so as to still retain essentially the same function, structure, identity, and feedbacks" [41] (p. 1). Adaptive landscape governance recognises threats and vulnerabilities and encompasses actions that address them and allow for recovery after disturbances. This is done by steering towards maintaining landscape attributes that provide resilience to undesirable changes [15]. Resilient landscapes are multifunctional landscapes which provide food security, livelihood opportunities, biodiversity and other environmental services, including carbon sequestration and cultural services [42]. This implies the integration of conservation and productive uses within the same landscape [15], referred to in the literature as "sharing" $[43,44]$.

\subsubsection{Multi-Stakeholder Negotiation}

Adaptive landscape governance engages multiple stakeholders in decision-making. These actors - public and private and operating at different levels of scale - have different values and aspirations. Negotiation on goals, desired transformations and trade-offs is therefore key [15]. As such, adaptive governance is what Kooiman and Bavinck [19] labelled "interactive governance". "Negotiation" features prominently in these interactions, as reflected in the principles for a landscape approach [15] such as "Common entry point" (negotiated and shared goals) and "Negotiated and transparent change logic" (all stakeholders understand, accept and agree on the course of action, and are aware of the options, opportunities, risks and uncertainties) [15] (p. 8351). The landscape approach (and landscape governance for that matter) puts more emphasis on negotiated goals and change logic than adaptive governance does, but is as yet not very specific about the institutions through which these negotiations should be organised [40]. 
Table 1. Characteristics of adaptive co-management, co-governance and landscape governance.

\begin{tabular}{|c|c|c|c|c|}
\hline Characteristic & Co-Management & Adaptive Co-Management & Adaptive Governance & Landscape Governance [15] \\
\hline Scale & $\begin{array}{l}\text { Oriented towards community-level } \\
\text { resource users [12] }\end{array}$ & $\begin{array}{l}\text { Tailored to specific places } \\
\text { (community level) [3] }\end{array}$ & Involving multiple scales $[4,6]$ & Landscape scale, involving multiple scales \\
\hline Scope & $\begin{array}{c}\text { Oriented towards sustainable } \\
\text { management of common pool } \\
\text { resources (forests, fisheries) [12]. } \\
\text { Focused on sustainable provision } \\
\text { of products and ecosystem } \\
\text { services [12] }\end{array}$ & $\begin{array}{l}\text { Largely resource-oriented, but } \\
\text { situating resource use in social } \\
\text { ecological systems (SES) }[4,5] . \\
\text { Oriented towards problem } \\
\text { solving [12] }\end{array}$ & $\begin{array}{l}\text { Integrated approach focusing on social } \\
\text { ecological systems (SES) [4]. } \\
\text { Oriented towards building adaptive } \\
\text { capacity and resilience to cope with change, } \\
\text { disturbances and uncertainty }[4,6,7]\end{array}$ & $\begin{array}{l}\text { Integrated approach focusing on } \\
\text { multifunctional landscapes that provide } \\
\text { multiple values, products and services. } \\
\text { Oriented towards increasing resilience and } \\
\text { maintaining landscape attributes that } \\
\text { provide resilience to undesirable changes }\end{array}$ \\
\hline $\begin{array}{c}\text { Actor } \\
\text { constellations }\end{array}$ & $\begin{array}{l}\text { Power and responsibilities shared } \\
\text { between government agencies } \\
\text { and local resource users [12] }\end{array}$ & $\begin{array}{c}\text { Power and responsibilities shared } \\
\text { between government agencies and } \\
\text { local resource users [12]. } \\
\text { Supported by organisations from } \\
\text { multiple scales [1]. } \\
\text { Flexible institutional } \\
\text { arrangements \& networks }[4,10]\end{array}$ & $\begin{array}{c}\text { Collaboration between public and private } \\
\text { actors operating at multiple scales }[4,7,10] \text {. } \\
\text { Polycentric governance arrangements based } \\
\text { on organisational and institutional } \\
\text { flexibility }[45,46] . \\
\text { Social capital (trust, reciprocity, common } \\
\text { rules, norms and sanctions, and } \\
\text { connectedness in networks and groups) as a } \\
\text { basis for self-organisation }[1,10,23,24] \text {. } \\
\text { Rules and enforcement }[47]\end{array}$ & $\begin{array}{l}\text { Multiple stakeholders equitably engaged in } \\
\text { decision-making, requiring conflict } \\
\text { management, trust, dealing with power } \\
\text { differences, and transaction costs. } \\
\text { Negotiated and shared goals and transparent } \\
\text { change logic. Clarification of rights and } \\
\text { responsibilities, including rules of resource } \\
\text { access and land use, a fair justice system for } \\
\text { conflict resolution and recourse, and } \\
\text { negotiation of conflicting claims }\end{array}$ \\
\hline $\begin{array}{l}\text { Role of } \\
\text { learning }\end{array}$ & $\begin{array}{l}\text { Simple exchange of information } \\
\text { [12]; tendency to distrust local } \\
\text { and tacit knowledge [1] }\end{array}$ & $\begin{array}{l}\text { Based on self-organised } \\
\text { learning-by-doing }[3,9]\end{array}$ & $\begin{array}{l}\text { Ongoing learning to live with uncertainty } \\
\text { and change by combining multiple types of } \\
\text { knowledge [5]. Self-organisation to monitor } \\
\text { and respond to environmental feedbacks } \\
\text { based on social learning and trustworthy } \\
\text { information flows }[23,48]\end{array}$ & $\begin{array}{l}\text { Continual learning and adaptive } \\
\text { management. Strengthened stakeholder } \\
\text { capacity for effective participation. } \\
\text { Participatory and user-friendly monitoring } \\
\text { based on shared learning and information }\end{array}$ \\
\hline $\begin{array}{c}\text { Role of } \\
\text { bridging } \\
\text { organisations }\end{array}$ & Minimal or no role & $\begin{array}{l}\text { Important role for bridging } \\
\text { organisations to mobilise } \\
\text { resources, knowledge and } \\
\text { other incentives; knowledge } \\
\text { brokering) [1] } \\
\end{array}$ & $\begin{array}{l}\text { Bridging organisations facilitate cross-scale } \\
\text { interactions }[4,49] \text {. Leadership to build } \\
\text { trust, mobilise support and knowledge, and } \\
\text { manage conflicts }[4,6]\end{array}$ & $\begin{array}{l}\text { Bridging organisations do not receive a lot } \\
\text { of attention in the literature but play an } \\
\text { important role in practice }\end{array}$ \\
\hline
\end{tabular}

Source: Compiled from $[1,3-7,9,10,12,23,24,45-49]$. 
Table 2. Principles for adaptive landscape governance.

\begin{tabular}{|c|c|c|c|}
\hline Principle & Dimensions & Specification/Example & $\begin{array}{c}\text { Equivalent Principles of } \\
\text { Landscape Governance [15] }\end{array}$ \\
\hline \multirow{2}{*}{$\begin{array}{l}\text { Integrated } \\
\text { approach }\end{array}$} & $\begin{array}{l}\text { Integration of social and ecological } \\
\text { aspects [4] }\end{array}$ & $\begin{array}{l}\text { Landscapes as social-ecological systems-acknowledging social and } \\
\qquad \text { ecological dynamics }[43]\end{array}$ & Principle 9: Resilience \\
\hline & $\begin{array}{l}\text { Integration of conservation and } \\
\text { development aims [15] }\end{array}$ & $\begin{array}{l}\text { Targeting food security, environmental services (e.g., carbon } \\
\text { sequestration, biodiversity), and commodity production (e.g., } \\
\text { timber) }[35,42,43]\end{array}$ & Principle 4: Multifunctionality \\
\hline \multirow{3}{*}{$\begin{array}{l}\text { Multi-stakeholder } \\
\text { negotiation }\end{array}$} & Negotiation of goals [15] & Goals in terms of land-use (change), production targets [15] & $\begin{array}{l}\text { Principle 2: Common concern entry point } \\
\text { (shared values and objectives) }\end{array}$ \\
\hline & $\begin{array}{l}\text { Shared vision and negotiated change } \\
\text { logic [15] }\end{array}$ & $\begin{array}{l}\text { Consensus on objectives, challenges, options, opportunities, based on } \\
\text { awareness of risks and free, prior and informed consent (FPIC) [15] }\end{array}$ & $\begin{array}{c}\text { Principle 6: Negotiated and transparent } \\
\text { change logic }\end{array}$ \\
\hline & $\begin{array}{l}\text { Negotiation of } \\
\text { trade-offs [15] }\end{array}$ & $\begin{array}{l}\text { Which trade-offs between conservation and development or different } \\
\text { productive land uses do stakeholders consider as acceptable? [15] }\end{array}$ & Principles 2 and 6 \\
\hline \multirow{3}{*}{$\begin{array}{l}\text { Polycentric } \\
\text { governance }\end{array}$} & Hybridity [45] & $\begin{array}{l}\text { Mixed types of institutional arrangements, building on existing and new } \\
\text { ones e.g., traditional authorities, stools, CBAGs (community-based } \\
\text { advisory groups), forest forums }\end{array}$ & $\begin{array}{l}\text { Principle 5: Multiple stakeholders. } \\
\text { Principle 3: Multiple scales }\end{array}$ \\
\hline & $\begin{array}{l}\text { Clear rights, responsibilities, } \\
\text { benefits }[45]\end{array}$ & $\begin{array}{l}\text { Land-use rights, harvesting rights, responsibilities regarding tree planting } \\
\text { and maintenance, benefit-sharing arrangements }\end{array}$ & $\begin{array}{l}\text { Principle 7: Clarification of rights and } \\
\text { responsibilities }\end{array}$ \\
\hline & Legal options for self-organisation [45] & Taungya committees and associations & $\begin{array}{l}\text { Principle } 5 \\
\text { Principle 10: Strengthened } \\
\text { stakeholder capacity } \\
\end{array}$ \\
\hline \multirow{4}{*}{$\begin{array}{l}\text { Continual } \\
\text { learning }\end{array}$} & $\begin{array}{l}\text { Single loop-learning: improving } \\
\text { routines }[7,22]\end{array}$ & $\begin{array}{l}\text { Adapt day-to-day management practices, (e.g., greater spacing } \\
\text { between seedlings) or creating bylaws to refine existing regulations }\end{array}$ & $\begin{array}{l}\text { Principle 1: Continual learning and } \\
\text { adaptive management }\end{array}$ \\
\hline & $\begin{array}{l}\text { Double loop-learning: reframing } \\
\text { assumptions [7,22] }\end{array}$ & $\begin{array}{l}\text { Adapt assumptions about problems, goals and how best to achieve them, } \\
\text { e.g., allowing experimentation with cassava planting }\end{array}$ & $\begin{array}{l}\text { Principle } 8 \text { : Participatory and } \\
\text { user-friendly monitoring }\end{array}$ \\
\hline & $\begin{array}{l}\text { Triple loop-learning: transforming } \\
\text { underlying norms and values }[7,22]\end{array}$ & $\begin{array}{l}\text { Transformation of the structural context, e.g., a shift from reforestation to } \\
\text { a landscape approach }\end{array}$ & Principles 6 and 10 \\
\hline & Institutional memory [50] & Learn from monitoring and evaluation & Principle 8 \\
\hline
\end{tabular}


Table 2. Cont.

\begin{tabular}{|c|c|c|c|}
\hline Principle & Dimensions & Specification/Example & $\begin{array}{c}\text { Equivalent Principles of } \\
\text { Landscape Governance [15] }\end{array}$ \\
\hline \multirow{4}{*}{$\begin{array}{l}\text { Adaptive } \\
\text { capacity }\end{array}$} & Being prepared for change [47] & Flexibility to adapt alternative solutions (e.g., regarding cassava planting) & Principles $1,2,6,8,9$ \\
\hline & $\begin{array}{l}\text { Willingness to engage in collective } \\
\text { decision making and share } \\
\text { power }[51,52]\end{array}$ & Taungya associations with autonomy to design and implement bylaws & Principles $1,2,4,6,8$ \\
\hline & $\begin{array}{l}\text { Accept a diversity of solutions, actors } \\
\text { and institutions [50-52] }\end{array}$ & Accept different ways of solving a problem [50] & Principles 2, 4, 5, 6 \\
\hline & Room for autonomous change $[50]$ & $\begin{array}{l}\text { Enhancing actor capacity to self-organize and innovate; foster social } \\
\text { capital [50] }\end{array}$ & Principles 1 and 9 \\
\hline
\end{tabular}

Sources: Compiled from [4,7,15,22,43-45,47,50-55].

Table 3. Conditions enabling adaptive landscape governance.

\begin{tabular}{|c|c|c|}
\hline Enabling Condition & Dimensions & Specification/Example \\
\hline Social capital [55-57] & $\begin{array}{l}\text { - Relations of trust } \\
\text { - Reciprocity and exchange } \\
\text { - Common rules, norms and sanctions } \\
\text { - Connections in networks and groups }\end{array}$ & $\begin{array}{l}\text { - Relationship between the parties; room to discuss doubts } \\
\text { - Bonding social capital: local links between people with similar objectives, e.g., taungya farmers } \\
\text { - What do parties gain from the collaboration? Benefit-sharing agreement } \\
\text { - Jointly agreed formal \& informal rules \& sanctions } \\
\text { - Bridging social capital: horizontal linkages between groups that may have different views, e.g., between } \\
\text { communities, or between different government agencies (FC and MLNR) } \\
\text { - Linking social capital: vertical linkages with external agencies, e.g., between taungya farmers and stools, } \\
\text { government agencies, NGOs, international donors }\end{array}$ \\
\hline $\begin{array}{l}\text { Bridging organisations } \\
\quad[1,3,4,20,23,58]\end{array}$ & $\begin{array}{l}\text { - Long-term facilitation } \\
\text { - Leadership (visionary, entrepreneurial } \\
\text { and collaborative) }\end{array}$ & $\begin{array}{l}\text { - Long-term facilitation in mobilising actors, social capital, trust, financial means, political support, and } \\
\text { conflict management } \\
\text { - Vision, communication skills, and conflict-resolving capacity }\end{array}$ \\
\hline Long-term funding [23] & - Long-term financial commitment & $\begin{array}{l}\text { - Donor funding } \\
\text { - National arrangements e.g., proportion of royalties and/or export value }\end{array}$ \\
\hline
\end{tabular}

Source: Compiled from [1,3,4,20,23,55-58]. 


\subsubsection{Polycentric Governance}

Whereas co-management tends to focus on community-level resource users [12] and be "tailored to specific places" [3] (p.75), adaptive governance and landscape governance acknowledge cross-scale and multilevel linkages $[5,12,49]$. Cross-scale linkages are understood as being interactions between different scales (e.g., temporal, spatial, institutional, jurisdictional), whereas multilevel linkages are those between different organisational levels within a scale (e.g., from global to local on a geographical scale, or from constitutions to operational rules on an institutional scale) [49]. This is particularly clear in the case of reforestation [45] where implementation occurs at local levels, while policies, programmes and funds that make it possible mostly find their origin at the national and international level-with increasing involvement of sub-national levels due to decentralisation. Similarly, reforestation generates products and services relevant for users at the local level (fuelwood, interplanted food crops), national level (timber) and international level (carbon) [45]. Economic globalisation and global environmental change further increase the functional connectivity of natural resource use systems [59], resulting in horizontal and vertical collaboration between public and private actors $[5,7,19]$. Consequently, incentives, financial resources and accountability systems to safeguard the provision of goods and environmental services cannot be confined to one single level of governance [45]. Ostrom's design principles for the management of common pool resources are derived from local situations of self-governance and do not cover cross-scale and multilevel linkages and larger-scale governance sufficiently at, for instance, the landscape level [5,60]. "Polycentric governance" [61] has been proposed to cover different, but partly overlapping institutional units or centres of decision-making that operate at multiple scales and each have their own jurisdictions, rules of access and use, monitoring and sanction systems, and conflict resolution mechanisms [46,61]. This corresponds with arguments in favour of more diverse and nested governance structures (top-down, bottom-up, networks, side-by side arrangements). These include horizontal and vertical linkages and hybrid arrangements beyond the usual triptych of state, markets and civil society/community-based organisations) without dominance of any particular one [7,60,62]. Within each of the institutional units, clarity is required on rights, roles and responsibilities, as well as benefits. In addition, actors should be willing to comply with commonly agreed rules [47]. The institutional flexibility associated with polycentric governance differs from the notion of multilevel governance which assumes a hierarchical order between different governance units.

\subsubsection{Continual Learning}

Landscapes are social-ecological systems subject to dynamic and unpredictable change [4,41]. Whereas conventional co-management is generally based on equilibrium (optimum state) thinking, adaptive approaches acknowledge that social-ecological systems may shift between alternative states [48]. Coping with these dynamics - which are exacerbated by climate change and economic globalisation [20,53] — requires a learning approach, adaptive management [15] and an overall willingness to learn from mistakes [51]. Although training and capacity building are conditional for successful adaptive management [5], learning goes beyond this. It is essentially a reflective process of diagnosing, designing, implementation and evaluation [10] that builds on different types of knowledge 
(experiential and experimental; scientific and local) [54]. Several learning approaches have been documented in the literature. Armitage et al. [22] and Pahl-Wostl et al. [7] distinguish between single loop-learning (fixing errors by improving routines), double loop-learning (correcting errors by reframing assumptions), and triple loop-learning (transforming underlying norms, values and governance protocols resulting in new policies, regulatory frameworks and actor networks). Gupta et al. [50] add to this trust, discussing doubts, and institutional memory. Bridging organisations (see Section 2.2) play an important role in learning processes as brokers of knowledge from multiple sources [1].

\subsubsection{Adaptive Capacity as Preparedness for Change}

Adaptive co-management and landscape governance require adaptive capacity. Definitions differ, but generally refer to the ability of "social actors to act collectively in the face of internal and external threats to the use and protection of common resources" and "to flexibly adapt to change and respond to disturbances" [51] (p. 704) and "the ability of a resource governance system to first alter processes and if required convert structural elements as response to experienced or expected changes in the societal or natural environment" [7] (p. 355). The concept has been operationalised in several ways. Armitage [51], based on Berkes et al. [52], identified a willingness to (i) learn from mistakes; (ii) engage in collaborative decision-making arrangements and share power; and (iii) accept institutional diversity_partly already covered by "polycentric governance" and "continual learning" above. Focusing on institutions, Gupta et al. [50] defined six criteria for adaptive capacity, namely (i) variety (of problem frames, solutions, actors); (ii) learning capacity (single and double loop-learning, but also trust and institutional memory); (iii) room for autonomous change (continuous access to information, capacity to act according to plan, and capacity to improvise); (iv) leadership (visionary, entrepreneurial and collaborative); (v) resources (authority, human, financial) and (vi) fair governance (legitimacy, equity, responsiveness, accountability). As a general principle for the purpose of this paper, we summarise adaptive capacity as the overall preparedness for change and sharing power [47,51].

\subsection{Enabling Conditions}

\subsubsection{Social Capital}

If co-management is more about managing relationships than resources [63], this applies even more so to adaptive landscape governance, with its cross-scale and multi-level learning and negotiation processes. Several authors $[1,10,23,24,56]$ therefore stress the importance of social capital as an essential precondition for self-organisation, collective action and adaptive (landscape) governance. Social capital is thereby understood as "relations of trust; reciprocity and exchanges; common rules, norms and sanctions; (and) connectedness (in) networks and groups" [57] (p. 211) [55] (p. 1913). As regards connectedness in networks and groups, all types of social capital are needed: bonding social capital that ensures group cohesion, trust building and self-organisation at one particular level; bridging social capital that enables horizontal links between groups that may have different views; and linking capital that enables networks and alliances across scales and levels [55]. 


\subsubsection{Bridging Organisations}

Creating the conditions for self-organisation and cross-scale institutional linkages are amongst the biggest challenges of adaptive co-management (and hence also for adaptive landscape governance) [23]. Facilitation, access to reliable information, legal options for the formation of decision-making bodies, and conflict management mechanisms to deal with conflicting values and power imbalances are essential preconditions [23]. Bridging organizations - research organisations, NGOs or, as in the case described by Hahn et al. [58] an eco-museum - can play a pivotal role in this respect by mobilising actors, funds and political support, brokering information and knowledge from different sources, building trust and social capital, mediating conflicts, networking and communication across scales, and creating platforms for collective learning [1,4,20,58]. Bridging organisations facilitate linkages between communities, NGOs, government agencies, research organisations, and other partners in collaborative arrangements [1]. They are particularly important at the landscape level, where boundaries often do not coincide with administrative jurisdictions. Leadership (including communication skills and conflict management capacity) and vision are more important than the organisational structure of such bridging organisations [1,3,58], but formal recognition and support may reduce their vulnerability [58]. The same applies to long-term funding of such organisations [23].

\subsubsection{Long-Term Funding}

Long-term funding has also been identified as a pre-condition for adaptive decision-making [23]. As noted above, bridging organisations may play a key role in mobilising and securing such funds [58].

\subsection{Data Sources}

Two case studies on the MTS were carried out between 2010 and 2012 in Ghana's high forest zone [27,29]. A study on the livelihood effects of the MTS was carried out in eight villages bordering three forest reserves where the MTS had been implemented (the Tano-Offin, Tain II and Yaya forest reserves). Two MTS modalities were covered: the national MTS scheme implemented by the Forest Services Division (FSD) of the Forestry Commission (FC) and the MTS carried out within the framework of the African Development Bank (AfDB)-sponsored Community Forestry Management Project (CFMP) implemented by the Ministry of Land and National Resources (MLNR), with involvement of the Ministry of Food and Agriculture (MOFA) and NGOs. Data was collected between August 2009 and November 2010 using a survey among 146 MTS farmers (65 men, 81 women); focus group discussions in one village per forest reserve involving 76 MTS farmers; and 20 key respondent interviews with staff of the National Forest Plantation Development Centre (NFPDC), range supervisors of the FSD, and MTS leaders. The survey sample represented $68 \%$ of all farmers in the study villages and $77 \%$ of the MTS farmers. Respondents were selected on the basis of information from range supervisors of the Forest Services Division of the FC and MTS leaders. The survey yielded information on personal characteristics (age, sex, marital status and household size), socio-economic background (schooling, place of origin, farmers' economic activities), tree and crop species planted, motivation and expectations regarding participation in the scheme, benefits received from the MTS and 
perceptions of governance aspects, effects and challenges. The survey data was analysed using Statistical Package for Social Sciences (SPSS). Issues raised during the survey (particularly regarding governance aspects, benefits, livelihood strategies and perceptions of performance and challenges of the scheme) were discussed in more detail in the focus groups. Key respondent interviews were about governance arrangements, area planted, benefit-sharing arrangements, and perceptions of challenges among staff of the implementing organisations.

The second study focused on livelihood and resource conflicts under different governance arrangements and was carried out in the Tano-Offin reserve in the Ashanti region where protection, production and reforestation regimes can be found, and where off-reserve conditions could be studied in the villages bordering the reserve. This paper uses insights from the studies in the villages of Chirayaso (Atwima Mponua District) and Kunsu-Nyamebekyere No. 3 (Ahafo Ano South District) that were engaged in the MTS. In these villages, too, mixed methods were used, including community meetings, a survey and validation meetings. For the survey $(n=212 ; 98$ women, 114 men $)$ a semi-structured questionnaire was used with questions that focused on the livelihood effects of the MTS and the conflicts associated with the scheme. Focus groups were organised with 36 and 45 community members respectively in the two villages to validate the survey findings and to facilitate follow-up discussions. Open interviews were held in January 2011 with four officials from the Resource Management Support Centre (RMSC) and the Forest Services Division of the Forestry Commission about the future of the scheme. Literature review and content analysis of policy and project documents complemented the data of both studies.

The case studies provided considerable insight into the performance of the scheme, but the data was collected for purposes that differ from the objective of this paper. To compensate for this limitation, additional literature was reviewed and experts consulted during the First National Forestry Congress of Ghana (September 16-17, 2014). Two experts kindly agreed to review an earlier version of this paper (October 2014) (see acknowledgements).

\section{Results: the MTS and Criteria for Adaptive Landscape Governance}

\subsection{Principle 1: Integrated Approach}

The MTS is potentially an integrated approach in the sense that it combines multiple aims: commodity production (timber), food security, and (implicitly) carbon sequestration. In its design, however, it is primarily meant to produce timber, as interplanting food crops is possible only until canopy closure ( 3 years on average). A total of 94,115 ha of degraded forest reserve land have been reforested under the national scheme (80,727 ha) and the CFMP (13,388 ha) between 2002 and 2012 [64]. This provides a future income source to an estimated 109,000 rural families [65] (cited in [25]).

The carbon potential of plantations and agroforestry has been acknowledged (e.g., [66-68]), but might be less promising than generally assumed. A study based on a small sample of reforestation schemes in degraded forest reserves of Ghana generated lower than average values [69]. Moreover, carbon benefits are gone after harvesting unless the timber is used in durable products. In the case of short-rotation plantations, this applies to only $20 \%$ of stored carbon on average [70]. Finally, the 
benefits to farmers are not guaranteed due to volatile carbon markets and declining carbon prices [71]. The role of the MTS might therefore be more promising in terms of climate change adaptation, as trees improve water utilisation, microclimate, soil productivity, nutrient cycling, control of pests and diseases, farm productivity, income diversification and farm income, thus enhancing the resilience of farming systems [68].

Future timber and carbon benefits are jeopardised by disincentives to tree maintenance such as a lack of short-term benefits, limited trust due to unsigned benefit-sharing agreements (only 296 of the 2300 MTS farmer groups have signed benefit-sharing agreements [64], risks of wildfire, theft by chainsaw operators, seedling destruction by cattle (Fulani herdsmen), insecure tenure, unstable carbon markets, and uncertainty about how group benefits will be shared among individual farmers [27-30,64,68,71,72].

The greatest benefit of the MTS are its short-term livelihood effects, based on (i) income from food crops; (ii) income from seedling production; and (iii) indirect income resulting from re-investment of MTS revenues in petty trade and micro-enterprises. Among the respondents, this resulted in greater food security throughout the year, better quality housing, and improved school attendance by children [27-30]. However, these effects disappear after canopy closure when food crops can no longer be grown. To summarise, the MTS has the potential to integrate multiple goals, but dealing with risks and long-term insecurity need to be addressed to enable long-term benefits (see also Sections 3.4 and 3.7).

\subsection{Principle 2: Multi-Stakeholder Negotiation}

The MTS was the result of an 18-month negotiation process that was organised by the government of Ghana in 2001-2002 among farmers, land owners, local communities and NGOs, after the failure of the traditional taungya system (see also Section 1). A lack of benefits from timber trees and decision-making power under the old system caused farmers to neglect or destroy the trees and to use the scheme to expand their farming land illegally into forest reserves. This resulted in the suspension of the taungya scheme in 1984. The outcome of the 2001-2002 consultation process (which was supported by the FAO and the World Bank) was the proposal for the modified taungya system in which farmers were entitled to a share in the future timber benefits and institutions were put in place to give farmers decision-making power in the management of the scheme [73]. The MTS was developed and piloted by the Collaborative Resource Management Unit of the RMSC in the early 1990s with support from the then Overseas Development Agency (now Department for International Development-DFID) [32].

The national MTS had a multi-stakeholder design, involving the FSD, farmers, communities and traditional authorities. However, this institutional design left little space for negotiation by the farmers, as the FC set the rules regarding the selection of tree species, the way in which they had to be planted (row planting and $3 \times 3 \mathrm{~m}$ spacing), and which food crops were allowed [27,28]. The FC justified these choices based on prior field trials and community consultation [32]. The MTS farmers and their committees were not consulted prior to suspending the scheme in 2010, negating them negotiation power [27]. 
Multi-stakeholder negotiation is, however, inevitable where conflicts jeopardise the continuity of the scheme. This happened in Chirayaso, where a conflict emerged about the disproportionate allocation of MTS plots to executives, excluding 58 community members from access to MTS land [27]. Negotiation through mediation by FSD officials, involving local traditional authorities (chiefs and elders), MTS farmers and other community members, resulted in re-demarcation and re-allocation of MTS plots, allocation of additional forest reserve land to the scheme for excluded farmers, and re-election of the MTS committee.

Multi-stakeholder negotiation was embedded more effectively within the framework of the CFMP: donor funding of the AfDB enabled more investments in capacity building and social organisation, enhancing the farmers' bargaining power. MTS groups were organised in associations which negotiated the creation of bylaws that enhanced efficient MTS operation and, in one of the cases, successfully negotiated experimentations with interplanting cassava, which was initially forbidden based on the assumption that it would disturb the growth of timber trees (see Section 3.4). Stronger social organisation (see also Section 3.5) and negotiating capacity, combined with investment in income-generating projects in small-stock rearing and seedling production, enhanced farmers' commitment to the scheme with positive effects on the condition of the plantations $[29,30]$.

The examples show that different actors may have different interests in the MTS, but also that multi-stakeholder negotiation provides better perspectives for combined objectives - in this case, timber production, food production and livelihood improvement.

\subsection{Principle 3: Polycentric Governance}

Designed as one of the strategies under the 2001 National Forest Plantation Development Programme, the institutional design of the national MTS and the rights and obligations of the parties are stipulated in the Modified Taungya Agreement (MTA) [71]. Farmers interested in the scheme are to form an MTS group and select a taungya committee (officially: Land Allocation and Taungya Management Committee) responsible for pegging and plot distribution among the group members, overseeing tree planting, and compliance of guidelines by the parties (particularly the FC and farmers), instituting sanctions, facilitating stakeholder consultation, settling disputes, and overall coordination, including of nursery and alternative livelihood activities where applicable [72] (p. 26). A benefit-sharing agreement sets out the rights, responsibilities and benefits of the parties involved (Table 4). This arrangement implicates links across several scale levels: jurisdictional (local authorities, stools, national government), institutional (operating rules, laws and regulations, the constitution) and spatial (from local to national) [49]. Hybridity and polycentric decision-making within the scheme is however not recognised; the national scheme can be labelled as hierarchical governance, with exceptions made only when conflicts emerge [27] (see Section 3.3). 
Table 4. MTS key stakeholders, their interest, responsibilities and benefits.

\begin{tabular}{|c|c|c|c|}
\hline Key Stakeholder & Interest & Responsibility & Benefits \\
\hline $\begin{array}{c}\text { Forestry } \\
\text { Commission (FC) }\end{array}$ & $\begin{array}{l}\text { Need to restore degraded forest reserves and } \\
\text { address timber deficit; implementing the } \\
\text { Forest Development Master Plan }\end{array}$ & $\begin{array}{l}\text { Demarcation of degraded forest reserves; supplying the MTS farmers } \\
\text { with pegs and seedlings; providing training and extension services; } \\
\text { marketing and accounting of the plantation products; financial } \\
\text { management and supervision; fire prevention and control }\end{array}$ & $\begin{array}{l}\text { A } 40 \% \text { share in the timber } \\
\text { revenues; restoration of degraded } \\
\text { forest reserves; tree ownership }\end{array}$ \\
\hline MTS farmers & $\begin{array}{l}\text { Land to grow food crops; livelihood } \\
\text { improvement; co-ownership of trees; share in } \\
\text { timber revenues }\end{array}$ & $\begin{array}{l}\text { Provision of labour for site clearing, pegging, tree planting and } \\
\text { maintenance, and wildfire protection; fire prevention and control }\end{array}$ & $\begin{array}{l}\text { Revenues from food crops; } \\
\text { a } 40 \% \text { share in timber revenues; } \\
\text { co-ownership of trees with the FC }\end{array}$ \\
\hline $\begin{array}{l}\text { Stool landowner and } \\
\text { traditional authority }\end{array}$ & Investment in forest land; royalties & $\begin{array}{l}\text { Provision of land within the degraded forest reserve; guaranteeing } \\
\text { uninterrupted access to the allocated land }\end{array}$ & $\begin{array}{l}\text { A } 15 \% \text { share in the timber } \\
\text { revenues; land ownership }\end{array}$ \\
\hline Local community & $\begin{array}{l}\text { Availability of natural resources and farming } \\
\text { land; share in timber revenue as SRA * }\end{array}$ & $\begin{array}{l}\text { Assisting the } \mathrm{FC} \text { to prevent and control fire outbreaks and illegal } \\
\text { activities within the plantation }\end{array}$ & $\begin{array}{l}\text { A } 5 \% \text { share in timber } \\
\text { revenues as SRA * }\end{array}$ \\
\hline Timber companies & Secure supplies of timber & $\begin{array}{l}\text { Payment of an export levy on unprocessed air-dried timber as one of } \\
\text { the funding sources of the scheme }\end{array}$ & $\begin{array}{l}\text { Option to buy timber at the } \\
\text { prevailing market price }\end{array}$ \\
\hline
\end{tabular}

* The Social Responsibility Agreement (SRA) is an arrangement in the timber sector that stipulates that communities should be compensated for their efforts to protect the forest or plantation; source: Adapted from [28]. 
This was different for the MTS under the CFMP. Here broader partnerships were formed involving public actors other than the FC (Ministry of Land and Natural Resources, Ministry of Food and Agriculture, Ministry of Feeder Roads, and the Forestry Research Institute of Ghana), donors (the AfDB, the Global Environmental Facility (GEF) small grants programme, and the World Bank), NGOs, and in some cases the private sector [30,71]. This created hybrid governance constellations (top-down, bottom-up, and side-by side arrangements) implying polycentric governance and decision-making through bylaws designed and implemented by farmer associations [29] and the influence of project and private governance with their own norms and rules [74]. This broader partnership contributed to better results in terms of livelihood effects and plantation development compared to the national scheme [30].

\subsection{Principle 4: Continual Learning}

"Learning" as perceived by the respondents referred to the development of skills in seedling production and tree planting (all schemes) and in small-stock rearing (sheep and goats and, on an experimental basis, occasionally grasscutters) and other income-generating activities under the CFMP. These skills were learned in meetings or through field visits organised by the district FSD (all schemes) and/or the field coordinators and NGOs engaged in the CFMP. Although these forms of learning were intended to improve day-to-day management of tree farms, they cannot be labelled as single-loop or adaptive learning as they did not involve a process of evaluating and redesigning as part of a continual learning and adaptation process. Training was meant to transfer skills, rather than to learn from past mistakes and develop a resilient system. No mechanisms were put in place to evaluate the merits and demerits of the scheme as a basis for its improvement.

Occasional examples of double loop-learning (correcting errors by reframing assumptions) and triple loop-learning (transforming underlying norms, values and governance protocols) were identified however. An example of double loop-learning was found in the Yaya forest reserve [29,30]. Despite being the major staple and cash crop for Ghanaian farmers, planting cassava in the MTS was forbidden out of fear that the plants would overshadow the seedlings and prejudice tree growth due to competition for nutrients. Farmers in the Yaya forest reserve under the CFMP however challenged this assumption and succeeded in convincing the FSD range supervisor that cassava can be successfully integrated in the MTS. They demonstrated that the cassava provided some shade for the saplings, helping them to survive in the dry season. The experiment also made clear that permission to plant cassava incentivized the participants to better maintain the tree farms during the first four years of MTS establishment, which are critical for a good timber tree stand. Permitting cassava therefore had the potential to increase the timber tree stocking rate, challenging the assumption that it would prejudice the growth of timber trees. Although this did not stop the general ban on planting cassava in the MTS, at least in the Yaya forest reserve it was conditionally allowed as a result of double loop-learning.

Triple loop-learning (transforming the underlying governance protocols) occurred when the original taungya system was replaced with the modified taungya system following a broad consultation process (Sections 1 and 3.2). 


\subsection{Principle 5: Adaptive Capacity as Overall Willingness to Change}

Rather than being an adaptive system that embraces joint decision-making, the national MTS portrayed features of a fixed system designed primarily to serve the (timber) interests of the state [27]. The lack of incentives to maintain timber trees was the main motivation to change from the traditional to the modified taungya system, but the MTS itself was not designed as an adaptive system. Willingness to share power, accept a diversity of solutions, actors and institutions, and create room for autonomous change was observed only in the CFMP.

\subsection{Enabling Condition 1: Social Capital}

A difference was also observed between the national scheme and the MTS under the CFMP with regard to social capital. Although social capital was enhanced to some extent in both cases through the organisation of farmers in MTS groups, the Chirayaso case (Section 3.2) illustrated that this does not automatically create trust and bonding capital. Rather, it may result in local conflict and elite capture [27,71]. Bridging capital was created to some extent by organising field visits to other MTS schemes. Linking capital was absent in the national scheme, in which farmers only dealt with FSD Officers, and only did so infrequently. In none of the national MTS cases studied in our research was the FSD part of the taungya committee as stipulated in the guidelines. Under the CFMP, by contrast, MTS groups were organised into associations where cooperative capacity was built and bonding social capital was created. Meetings were organised where social matters were discussed and farmers organised welfare activities (e.g., mobilising funds for bereaved members), engaged in noboa (cooperative farming) for tree planting and maintenance, and cooperated in seedling production and alternative livelihood projects such as piggery and rearing small ruminants (sheep and goat). This greater cooperative capacity resulted in a greater commitment to (a) MTS rules and by-laws created by the associations; (b) recommended planting techniques regarding spacing and planting in rows; (c) maintaining the tree farms after removal of the food crops; (d) prompt joint action to protect tree farms against fire outbreaks and illegal tree felling; and (e) mutual support [29]. Bridging social capital was created through the organisation of field visits to other MTS schemes, and linking capital through engagement with external NGOs and private companies.

\subsection{Enabling Condition 2: Bridging Organisations}

Within the CFMP there were several bridging organisations that mobilised actors and funds, brokered information, actively engaged in building trust and social capital, and meditated in conflicts. The CFMP secretariat hosted by the Forest Plantation Development Centre of the MLNR played a key role in this respect. It employed field coordinators who actively engaged with the farmers and channelled funds from the AfDB, the Government of Ghana, and the GEF Small Grants Programme to support alternative livelihood activities. The CFMP secretariat was the node of cross-scalar relations with other public agencies and ten NGOs [75] that were involved in the CFMP. The most active NGOs were the Conservation and Development Foundation (CONDEF), Tropenbos International Ghana and the Ghana Association for the Conservation of Nature (GACON). 
The bridging organisation was not sustainable and collapsed with the end of AfDB funding in 2010. Currently, there is no known public or private organisation that has taken up the task of empowering the MTS committees to become self-sustaining bodies capable of articulating their needs, and dialogue and negotiate their rights regarding future timber benefits. There is no endogenous process with the potential to generate such organisation: farmers' expectations in this regard are framed in terms of hierarchical relationships with supporting organisations, from which they expect "education of the farmers about the principles of the MTS", "monitoring compliance with obligations regarding tree planting and maintenance", and "early detection and mediation of potential conflicts" [27].

\subsection{Enabling Condition 3: Long-Term Funding}

During AfDB funding, MTS schemes under the CFMP performed well, with active investments in the building of social capital and income-generating projects. The CFMP was a six year project which was extended for two more years, after which exit strategies were put in place and the established plantations were handed over to the FC [32]. Since then the livelihoods and income generation component of the programme, and hence its integrated character, was less prominent and in most villages came to a standstill.

\section{Discussion: From Co-Management to Adaptive Landscape Governance}

The national MTS was not designed as an adaptive learning process and the scheme lacked the organisational flexibility to evolve as such. Several lessons can, however, be learned from the CFMP which we address in the sub-section below. After that, we highlight the challenges ahead.

\subsection{Lessons Learned from the CFMP}

First, expanding the focus beyond the mandate of the FSD (reforestation of degraded forest reserves to create future timber stocks) offers a broader scope for multiple objectives, including food production, diversification of livelihoods, and climate change mitigation and adaptation. The inclusion of off-reserve areas offers better perspectives for such an integrated approach, since farming in forest reserves is not allowed beyond temporary intercropping in the MTS. An attempt in this direction was made in 2010 when the FC introduced the Expanded Plantation Programme (EPP) that covers private lands in off-reserve areas. Going beyond the traditional mandate of the FC requires cross-sectoral partnerships involving other public actors (ministries, agencies and research organisations dealing with forestry, natural resources, agriculture, land-use planning and infrastructure development), civil society (NGOs and community-based organisations), and actors from the private sector.

Second, multi-stakeholder negotiation considerably enhances farmers' and other actors' commitment to the scheme. This requires an institutional framework to accommodate the negotiation of goals, challenges, opportunities and trade-offs and to give farmers and other actors at community level a voice in the negotiations. The FC created a basis for multi-stakeholder negotiation when it introduced the National Forest Forum (NFF) in 2007 as a platform for multi-stakeholder dialogue coordinated by the Collaborative Forest Management Unit of the FC at district, regional and national levels. The Forest Forum offers a basis to negotiate policy concerns, competing interests, rights, 
obligations and benefit sharing, whereby its multilevel design opens up the negotiations for actors at the local level [72]. NGOs participating in the Forest Forum act as watch dogs to defend social and environmental interests. The NFF-Ghana has played an advocacy role in ensuring that all the benefit-sharing agreements with MTS farmers were eventually signed and in August 2014 the forum sent a communiqué to the Minister of Land and Natural Resources asking for the reintroduction of the MTS in Ghana [32].

Third, the CFMP showed that institutional flexibility and polycentric governance improved the performance of the scheme. It resulted in hybrid institutions, including new (taungya groups and associations) and old (traditional authorities, the Stool), each with their own rules, including both formal regulations and locally designed bylaws.

Fourth, the presence of a bridging organisation capable of crossing jurisdictional and institutional boundaries, mobilising and channelling funds, and active engagement with actors across sectors and scales, proved to be of eminent importance for the creation of relations of trust (bonding capital), horizontal relations between different taungya groups and between different government agencies (bridging capital), and vertical locations that connect local communities to public and private actors at national and international level (linking capital). Active involvement of civil society organisations can help empower MTS farmers.

There are, however, also challenges that need to be dealt with before the MTS can be re-activated and scaled up as a landscape approach.

\subsection{Challenges Ahead}

Long-term funding appeared to be crucial; with the end of AfDB funding there was no longer any active engagement with the MTS schemes in the study sites. The transformation to holistic landscape governance requires political and financial commitment at national level, for instance in the form of a fixed percentage of timber royalties and export revenues. Another source of funding could be found in the ongoing Ghana Forest Investment Programme (GFIP) which targets three investment areas: (i) mitigation actions related to forests; (ii) investments outside the forest sector, primarily in agriculture and the cocoa sector, necessary to reduce the pressure on forests; and (iii) institutional capacity including forest management and information [76].

Second, a transformation is needed towards continual learning. Learning from past mistakes is needed to enhance adaptive capacity and to be able to deal with social and landscape dynamics. This requires a multilevel perspective that transcends local MTS implementation, as local communities are embedded in and affected by policies, processes and activities of actors at higher scale levels $[48,62]$. Examples of dynamics that are to be dealt with in Ghana are those associated with the national demand for timber, illegal chainsaw logging, and the inflow of migrants in search of farming land [27]. International policies and strategies also have an impact, such as the Voluntary Partnership Agreement (VPA) between Ghana and the European Union to combat illegal logging and Reduced Emissions from Deforestation and Degradation (REDD) policies [30,77]. The NFF-Ghana and bridging organisations like Tropenbos International Ghana (www.tropenbos.org) can play a role in social learning processes. However, Pahl-Wostl [7] warns that established formal networks run the risk of focussing on bargaining and single-loop-learning. She argues that to break away from existing policies 
and power constellations and achieve double and triple-loop learning, at least partially informal issue-based networks are needed. A network is informal if there are no fixed rules that define who takes part, who leads, and what is discussed [7]. An example is a group of policymakers and researchers who form a community of practice to seek novel solutions for a commonly felt problem. A community of practice is a "group of people who share a concern or a passion for something they do and learn how to do it better as they interact regularly" [78]. Learning platforms [40] that mediate between different knowledge systems and governance levels provide another example. They can act as catalysers by providing "an arena for knowledge co-production, trust building, sense making, learning, vertical and horizontal collaboration, and conflict resolution" [1] (p. 1695). Organisational flexibility that allows for informal knowledge brokering, experimental learning and iterative approaches is needed for genuine adaptive governance $[7,20,58,79]$.

Third, more attention is needed for conflict management. Adaptive governance and social learning require trust between parties with diverging interests and unequal powers [5]. Conflicts in natural resource management are therefore a rule rather than exception [5,27,80]. Conflicts with internal and external actors tend to exclude the weakest party from access to resources and livelihood options and affect motivation to engage in co-management negatively $[62,81]$. Self-organisation tends to decrease with growing and unresolved conflicts [23], but can be prevented where social capital is built and negotiation and communication mechanisms are put in place [24]. Conflicts, if properly dealt with, can positively affect a community's capacity to deal with external threats. As illustrated by the Chirayaso case, finding a solution for conflicts creates stability through clearer rights, more security and acceptable benefit sharing, and minimises risks of loss of investments and costs for conflict mediation [81].

Fourth, an important condition for the success of any scheme, be it under co-management or landscape governance, is economic incentives. Without being rewarded for their efforts or compensated for loss of livelihood opportunities no actor is willing to engage in natural resource management on a permanent basis $[21,23]$. Farmers engage more or less actively in tree planting and maintenance as long as there is a direct benefit (farming land to grow food crops), but long-term perspectives are currently too meagre to ensure this engagement on the long term [29,30]. This may also pose a challenge in getting stakeholders involved in landscape governance. A proposal from farmers is creating access to credit from banks and financial institutions with trees as collateral and the FC as guarantors. This would provide them with resources to maintain their farms and to cater for their other pressing needs [32].

Last, but not least, landscape governance requires willingness to change, to engage in collaborative decision-making and to accept institutional diversity and power sharing [15,23,51]. The Kumasi Resolution, adopted at the First Congress of Forestry on 17 September 2014, reflects this willingness where it states that "Meeting local livelihood needs while enhancing biodiversity and environmental goods and services at landscape scales requires new perceptions of responsibilities" [82]. Although this sounds hopeful, hierarchical relationships and a focus on the forestry mandate still tend to prevail [27]. 


\section{Conclusions}

Based on a review of literature, this paper highlighted three paradigm shifts in natural resource management: from co-management via adaptive co-management and adaptive governance, to adaptive landscape governance. It demonstrated how natural resource management is transforming towards landscape governance, with differences in scale (from local to landscape, recognizing multi-level interactions), scope (from sustainable management of common pool resources and environmental services towards an integrated approach aiming at multi-functional and resilient landscapes), and actor constellations (from an exclusive sharing of power and responsibilities between the state and local communities to a negotiated multi-stakeholder approach). With the shift from "management" to adaptive, multi-level, multi-actor "governance", the role of continual learning and bridging organisations have become essential features of natural resource governance.

The core features of adaptive landscape governance have been synthesised in five design principles (integrated approach, multi-stakeholder negotiation, polycentric governance, continual learning and adaptive capacity) and three enabling conditions (social capital, bridging organisations and long-term funding). This framework of principles and conditions was used to assess whether a reforestation scheme in Ghana (the modified taungya system) that was designed as a co-management scheme could be redesigned as an adaptive landscape approach. This analysis not only provided empirical reality for what is still a largely theoretical construct, but also aimed to contribute to informed decision-making on the revitalisation of the scheme, currently under discussion in Ghana.

The analysis of the MTS revealed a notable difference between the national MTS implemented by the Forest Services Division of the Forestry Commission and the one that was implemented by the Ministry of Land and Natural Resources and the Forestry Commission as part of the African Development Bank-financed Community Forestry Management Project. The national MTS was set up as a co-management scheme and functioned in a hierarchical manner. It reached a deadlock for failing to take account of landscape dynamics (wildfires, competing claims) and paradigm shifts in natural resource management. None of the principles of adaptive landscape governance apply to this scheme, while the enabling conditions were not met (bridging organisations, long-term funding) or only modestly so (some bonding and bridging social capital). In contrast, the MTS under the CFMP showed some potential for evolving into a landscape approach for several reasons. First, it went beyond a mere focus on reforestation with timber trees, thus offering room for an integrated approach aimed at improving timber stocks, food security, rural livelihoods and (although scarcely) carbon sequestration. Second, it transcended co-management by combining multiple stakeholders, including government, communities, NGOs and private sector. Third, it embraced institutional diversity by incorporating local decision-making bodies, both old (traditional authorities) and new (taungya committees), thus displaying features of polycentric governance. Fourth, it exhibited modest signs of continual learning and willingness to change (adaptive capacity). Enabling conditions were met through strong social capital building (bonding, bridging and linking), the involvement of bridging organisations, and, until 2010, long-term funding by the AfDB. It thereby met several principles and conditions for adaptive landscape governance.

This implies that a redesigned MTS should build on the experience within the CFMP. However, additional steps are needed before the model can be scaled up as a landscape approach. Long-term 
funding appeared to be a key issue. Integrated approaches and multi-stakeholder negotiation involve high transaction costs which are not readily available in a developing economy. Mobilising internal and donor funds is crucial and in this bridging organisations could play a key role. Further challenges involve continual learning and development of adaptive capacity, as well as transcending conventional levels of jurisdiction. Ghana's forestry sector is in transition and a new discourse on multi-functional landscapes is emerging. The challenge for the future is to implement this discourse in practice. Revitalising and redesigning the MTS along the principles outlined in this paper might be a first step.

\section{Acknowledgments}

We would like to thank Valerie Fumey Nassah (RMSC, Ghana) and Alex Asare (Collaborative Resource Management Unit of the RMSC) for their contributions to the ideas developed in this paper; Tropenbos International-Ghana for logistic and financial support to the fieldwork carried out for the case studies; Ton Dietz for valuable inputs during the implementation, data analysis and write up of the case studies; and two anonymous reviewers for their constructive comments. This paper was largely written during the first author's sabbatical stay at the Centre of International Forestry Research (CIFOR) in Bogor, Indonesia. She gratefully acknowledges the kind hospitality received as well as CIFOR's contribution to making this paper open access.

\section{Author Contributions}

Mirjam Ros-Tonen designed research for this paper and coordinated the research and writing process. She is the main author of the introduction and analytical framework. Mercy Derkyi and Thomas Insaidoo were responsible for the case studies and are the main authors of the section on data sources. All the authors are co-responsible for the analysis in the results section and for the discussion and conclusion.

\section{Conflicts of Interest}

The authors declare no conflict of interest.

\section{References}

1. Berkes, F. Evolution of co-management: Role of knowledge generation, bridging organizations and social learning. J. Environ. Manag. 2009, 5, 1692-1702.

2. Berkes, F. Rethinking community-based conservation. Cons. Biol. 2004, 13, 621-630.

3. Olsson, P.; Folke, C.; Hahn, T. Social-ecological transformation for ecosystem management: The development of adaptive co-management of a wetland landscape in southern Sweden. Ecol. Soc. 2004, 4. Available online: http://www.ecologyandsociety.org/vol9/iss4/art2/ (accessed on 4 July 2014).

4. Folke, C.; Hahn, T.; Olsson, P.; Norberg, J. Adaptive governance of social-ecological systems. Annu. Rev. Environ. Resour. 2005, 30, 441-473. 
5. Armitage, D.R.; Plummer, R.; Berkes, F.; Arthur, R.I.; Charles, A.T.; Davidson-Hunt, I.J.; Diduck, A.P.; Doubleday, N.C.; Johnson, D.S.; Marschke, M.; et al. Adaptive co-management for social-ecological complexity. Front. Ecol. Environ. 2009, 2, 95-102.

6. Olsson, P.; Gunderson, L.H.; Carpenter, S.R.; Ryan, P.; Lebel, L.; Folke, C.; Holling, C.S. Shooting the rapids: Navigating transitions to adaptive governance of social-ecological systems. Ecol. Soc. 2006, 11. Available online: http:/www.ecologyandsociety.org/vol11/iss1/art18/ (accessed on 4 July 2014).

7. Pahl-Wostl, C. A conceptual framework for analysing adaptive capacity and multi-level learning processes in resource governance regimes. Glob. Environ. Chang. 2009, 3, 354-365.

8. Plummer, R.; Armitage, D.R.; deLoë, R.C. Adaptive comanagement and its relationship to environmental governance. Ecol. Soc. 2013, 1. Available online: http://dx.doi.org/ 10.5751/ES-05383-180121 (accessed on 4 July 2014).

9. Borrini-Feyerabend, G. Co-Management of Natural Resources: Organising, Negotiating and Learning by Doing; IUCN: Yaoundé, Cameroon, 2000.

10. Plummer, R.; FitzGibbon, J. Connecting adaptive co-management, social learning, and social capital through theory and practice. In Adaptive Co-Management: Collaboration, Learning and Multi-Level Governance; Armitage, D., Berkes, F., Doubleday, N., Eds.; UBC Press: Vancouver, BC, Canada, 2007; pp. 38-61.

11. Pahl-Wostl, C.; Hare, M. Processes of social learning in integrated resources management. J. Community Appl. Soc. 2004, 14, 193-206.

12. Carlsson, L.; Berkes, F. Co-management: Concepts and methodological implications. J. Environ. Manag. 2005, 1, 65-76.

13. Armitage, D.; Marschke, M.; Plummer, R. Adaptive co-management and the paradox of learning. Glob. Environ. Chang. 2007, 1, 86-98.

14. Görg, C. Landscape governance: The politics of scale and the natural conditions of places. Geoforum 2007, 38, 954-966.

15. Sayer, J.; Sunderland, T.; Ghasoulc, J.; Pfund, J.L.; Sheilb, D.; Meijaard, E.; Ventera, M.; Boedhihartonoa, A.K.; Day, M.; Garcia, C.; et al. Ten principles for a landscape approach to reconciling agriculture, conservation, and other competing land-uses. PNAS 2013, 110, 8349-8356.

16. Van Oosten, C.; Gunarso, P.; Koesoetjahjo, I.; Wiersum, F. Governing forest landscape restoration: Cases from Indonesia. Forests 2014, 6, 1143-1162.

17. Mwangi, W.; Wertz, B. Global Landscape Forum Bulletin. A summary report of the Global Landscapes Forum. IISD Reporting Services 2013, 5, 1-14.

18. Holmgren, P. Negotiating the landscape approach. DG's blog. Thoughts from CIFOR's Director General. Available online: http://blog.cifor.org/25043/negotiating-the-landscapeapproach-holmgren\#.VGArR_mG-So (accessed on 10 November 2014).

19. Kooiman, J.; Bavinck, M. Theorizing governability-The Interactive Governance Perspective. In Governability of Fisheries and Aquaculture: Theory and Applications; MARE Publications Series No. 7; Bavinck, M., Chuenpagdee, R., Jentoft, S., Kooiman, J., Eds.; Springer: Dordrecht, The Netherlands, 2013; pp. 9-13.

20. Leys, A.J.; Vanclay, J.K. Social learning: A knowledge and capacity building approach for adaptive co-management of contested landscapes. Land Use Policy 2011, 3, 574-584. 
21. Pomeroy, R.S.; Cinner, J.E.; Nielsen, J.R.; Andrew, N.L. Conditions for successful co-management: Lessons learned in Asia, Africa, the Pacific, and the wider Caribbean. In Small-Scale Fisheries Management: Frameworks and Approaches for the Developing World; Pomeroy, R.S., Andrew, N., Eds.; Centre for Agricultural Bioscience International: Wallingford, UK, 2011; pp. 115-131.

22. Armitage, D.; Marschke, M.; Plummer, R. Adaptive co-management and the paradox of learning. Glob. Environ. Chang. 2008, 18, 86-98.

23. Cundill, G.; Fabricius, C. Monitoring the governance dimension of natural resource co-management. Ecol. Soc. 2010. Available online: http:/www.ecologyandsociety. org/vol15/iss1/art15/ (accessed on 4 July 2014).

24. Schröter, B.; Sessin-Dilascio, K.; Meyer, C.; Matzdorf, B.; Sattler, C.; Meyer, A.; Giersch, G.; Jericó-Daminello, C; Wortmann, L. Multi-level governance through adaptive co-management: Conflict resolution in a Brazilian state park. Ecol. Proc. 2014, 1, 1-13.

25. Agyeman, V.K. Promoting smallholder plantations in Ghana. Plantations and forest livelihoods. Arborvitae 2006, 31, 6.

26. Kalame, F.B.; Aidoo, R.; Nkem, J.; Ajayie, O.C.; Kanninen, M.; Luukkanen, O.; Idinoba, M. Modified taungya system in Ghana: A win-win practice for forestry and adaptation to climate change? Environ. Sci. Policy 2011, 14, 529-530.

27. Derkyi, M.A.A. Fighting over Forest. Interactive Governance of Conflicts over Forest and Tree Resources in Ghana's High Forest Zone; African Studies Centre: Leiden, The Netherlands, 2012.

28. Insaidoo, T.F.G.; Ros-Tonen, M.A.F.; Hoogenbosch, L.; Acheampong, E. Addressing forest degradation and timber deficits: Reforestation programmes in Ghana. ETFRN News. 2012, 53, 230-239.

29. Insaidoo, T.F.G. Forest Governance Arrangements and Innovations for Improving the Contribution of Ghana's Reforestation Schemes to Local Livelihoods. Ph.D. Thesis, Kwame Nkrumah University of Science and Technology, Kumasi, Ghana, 2013.

30. Ros-Tonen, M.A.F.; Insaidoo, T.F.G.; Acheampong, E. Promising start, bleak outlook: The Role of Ghana's Modified Taungya System as a Social Safeguard in Timber Legality Processes. For. Policy Econ. 2013, 32, 57-67.

31. Kasanga, K. Current land policy issues in Ghana. In Land Reform; FAO: Rome, Italy, 2003; pp. 141-154.

32. Fumey Nassah, V. Resource Management Support Centre, Kumasi, Ashanti Region, Ghana. Personal communication, 2014.

33. Scherr, S.; Shames, S.; Friedman, R. From climate-smart agriculture to climate-smart landscapes. Agric. Food Sec. 2012, 1. Available online: http://www.agricultureandfoodsecurity.com/ content/pdf/2048-7010-1-12.pdf (accessed on 4 July 2014).

34. FAO (Food and Agriculture Organization of the United Nations). Climate-Smart Agriculture Sourcebook; FAO: Rome, Italy, 2013.

35. Tscharntke, T.; Clough, Y.; Wanger, T.C.; Jackson, L.; Motzke, I.; Perfecto, I.; Vandermeer, J.; Whitbread, A. Global food security, biodiversity conservation and the future of agricultural intensification. Biol. Conserv. 2012, 151, 53-59. 
36. Insaidoo, T.F.G.; Ros-Tonen, M.A.F.; Acheampong, E. On-farm tree planting in Ghana's high forest zone: The need to consider carbon payments. In Governing the Provision of Ecosystem Services; Muradian, R., Rival, L., Eds.; Springer Publishers: Heidelberg, Germany, 2013; pp. $437-463$.

37. Shepherd, G. The Ecosystem Approach: Learning from Experience; IUCN: Gland, Switzerland, 2008.

38. Pfund, J.L. Landscape-scale research for conservation and development in the tropics: Fighting persisting challenges. Curr. Opin. Environ. Sustain. 2010, 1, 117-126.

39. Colfer, C.J.P.; Pfund, J.-P.; Sunderland, T. The essential task of "muddling through" to better landscape governance. In Collaborative Governance of Tropical Landscapes; Colfer, C.J.P., Pfund, J.-P., Eds.; Earthscan: London, UK, 2010; pp. 271-280.

40. Ros-Tonen, M.A.F.; van Leynseele, Y.P.B.; Laven, A.; Sunderland, T. Landscapes of social inclusion: Reassessing inclusive development through the lenses of food sovereignty and landscape governance. Eur. J. Dev. Res. 2014, submitted.

41. Walker, B.; Holling, C.S.; Carpenter, S.R.; Kinzig, A. Resilience, adaptability and transformability in social-Ecological systems. Ecol. Soc. 2004, 2. Available online: http://www.ecologyandsociety.org/vol9/iss2/art5 (accessed on 4 July 2014).

42. O'Farrell, P.J.; Anderson, P.M. Sustainable multifunctional landscapes: A review to implementation. Curr. Opin. Environ. Sustain. 2010, 1, 59-65.

43. Phalan, B.; Onial, M.; Balmford, A.; Green, R.E. Reconciling food production and biodiversity conservation: Land sharing and land sparing compared. Science 2011, 333, 1289-1291.

44. Kusters, K.; Lammers, E. Rich Forests-The Future of Forested Landscapes and Their Communities; Rich Forests Initiative, Both ENDS: Amsterdam, The Netherlands, 2013.

45. Nagendra, H.; Ostrom, E. Polycentric governance of multifunctional forested landscapes. Int. J. Commons. 2012, 2, 104-133.

46. Ostrom, E. Beyond markets and states: Polycentric governance of complex economic systems. Am. Econ. Rev. 2010, 100, 641-672.

47. Dietz, T.; Ostrom, E.; Stern, P.C. The struggle to govern the commons. Science 2003, 302, 1907-1912.

48. Berkes, F. Evolution of co-management: Role of knowledge generation, bridging organizations and social learning. J. Environ. Manag. 2010, 5, 1692-1702.

49. Cash, D.W.; Adger, W.N.; Berkes, F.; Garden, P.; Lebel, L.; Olsson, P.; Young, O. Scale and cross-scale dynamics: Governance and information in a multilevel world. Ecol. Soci. 2006, 2. Available online: http://www.ecologyandsociety.org/vol11/iss2/art8/ (accessed on 4 July 2014).

50. Gupta, J.; Termeer, C.; Klostermann, J.; Meijerink, S.; van den Brink, M.; Jong, P.; Nooteboom, S.; Bergsma, E. The adaptive capacity wheel: A method to assess the inherent characteristics of institutions to enable the adaptive capacity of society. Environ. Sci. Policy 2010, 13, 459-471.

51. Armitage, D. Adaptive capacity and community-based natural resource management. Environ. Manag. 2005, 6, 703-715. 
52. Navigating Social-Ecological Systems. Building Resilience for Complexity and Change; Berkes, F., Folke, C., Colding, J., Eds.; Cambridge University Press: Cambridge, UK, 2003.

53. Lemos, M.C.; Agrawal, A. Environmental governance. Annu. Rev. Environ. Resour. 2006, 31, 297-325.

54. Folke, C.; Carpenter, S.; Elmqvist, T.; Gunderson, L.; Holling, C.S.; Walker, B. Resilience and sustainable development: Building adaptive capacity in a world of transformations. AMBIO 2002, 5, 437-440.

55. Pretty, J. Social capital and the collective management of resources. Science 2003, 5652, 1912-1914.

56. Pretty, J.; Smith, D. Social capital in biodiversity conservation and management. Cons. Biol. 2004, 3, 631-638.

57. Pretty, J.; Ward, H. Social capital and the environment. World Dev. 2001, 2, 209-227.

58. Hahn, T.; Olsson, P.; Folke, C.; Johansson, K. Trust-building, knowledge generation and organizational innovations: The role of a bridging organization for adaptive co-management of a wetland landscape around Kristianstad, Sweden. Hum. Ecol. 2006, 34, 573-592.

59. Brondizio, E.S.; Ostrom, E.; Young, O.R. Connectivity and the governance of multilevel social- ecological systems: The role of social capital. Annu. Rev. Environ. Resour. 2009, 34, 253-278.

60. Cox, M.; Arnold, G.; Tomás, S.V. A review of design principles for community-based natural resource management. Ecol. Soc. 2010, 4. Available online: http://www.ecologyandsociety. org/vol15/iss4/art38/ (accessed on 4 July 2014).

61. Ostrom, V. Polycentricity (Part 1). In Polycentricity and Local Public Economics; McGinnis, M., Ed.; University of Michigan Press: Ann Arbor, MI, USA, 1999; pp. 52-74.

62. Fabricius, C.; Folke, C.; Cundill, G.; Schultz, L. Powerless spectators, coping actors, and adaptive co-managers: A synthesis of the role of communities in ecosystem management. Ecol. Soc. 2007, 1. Available online: http://www.ecologyandsociety.org/vol15/iss1/art15/ (accessed on 4 July 2014).

63. Natcher, D.C.; Davis, S.; Hickey, C.G. Co-management: Managing relationships, not resources. Hum. Organ. 2005, 3, 240-250.

64. FC (Forestry Commission). National Forest Plantation Development Programme (NFPDP): Annual Report 2013. Available online: http://www.fcghana.org/assets/file/Publications/ Forestry_Issues/National\%20Forest $\% 20$ Plantaion\%20Development $\% 20$ Programme/Annual\%20R eports/nfpdp_annual\%20report_2012.pdf (accessed on 20 October 2014).

65. Fumey Nassah, V. Resource Management Support Centre, Kumasi, Ashanti region, Ghana. Personal communication, 2012.

66. Winjum, J.K.; Schroeder, P.E. Forest plantations of the world: Their extent, ecological attributes, and carbon storage. Agric. For. Meteorol. 1997, 1, 153-167.

67. Ramachandran Nair, P.K.; Mohan Kumar, B.; Nair, V.D. Agroforestry as a strategy for carbon sequestration. J. Plant Nutr. Soil Sci. 2009, 172, 10-23.

68. Lasco, R.D.; Delfino, R.J.P.; Espaldon, M.L.O. Agroforestry systems: Helping smallholders adapt to climate risks while mitigating climate change. WIRES Clim. Chang. 2014, doi:10.1002/wcc.301. 
69. Yeboah, D.; Burton, A.J.; Storer, A.J.; Opuni-Frimpong, E. Variation in wood density and carbon content of tropical plantation tree species from Ghana. New For. 2014, 1, 35-52.

70. Schroeder, P.E. Carbon storage potential of short rotation tree plantations. For. Ecol. Manag. 1992, 50, 31-41.

71. Marfo, E.; Acheampong, E.; Opuni-Frimpong, E. Fractured tenure, unaccountable authority, and benefit capture: Constraints to improving community benefits under climate change mitigation schemes in Ghana. Cons. Soc. 2012, 2, 161-172.

72. Marfo, E. Security of Tenure and Community Benefits under Collaborative Forest Management Arrangements in Ghana: A Country Report; CSIR-INSTI: Accra, Ghana, 2009.

73. Agyeman, V.K.; Marfo, K.A.; Kasanga, K.R.; Danso, E.; Asare, A.B.; Yeboah, O.M.; Agyeman, F. Revising the taungya plantation system: New revenue-sharing Proposal from Ghana. Unasylva 2003, 1, 40-43.

74. Ingram, V.; Ros-Tonen, M.A.F.; Dietz, T. A fine mess: Bricolaged forest governance in Cameroon. Int. J. Commons. 2014, submitted.

75. FC (Forestry Commission). National Forest Plantation Development Programme (NFPDP): Annual Report 2008. Available online: http://theredddesk.org/sites/default/files/nfpdp_annual_ report_20081_2.pdf(accessed on 25 October 2014).

76. MLNR (Ministry of Land and Natural Resources) Climate Investment Funds. Forest Investment Program. Ghana Investment Plan, 2012. Available online: https://www. climateinvestmentfunds.org/cif/sites/climateinvestmentfunds.org/files/FIP_5_Ghana.pdf (accessed on 25 October 2014).

77. Wiersum, K.F.; Lescuyer, G.; Nketiah, K.S.; Wit, M. International forest governance regimes: Reconciling concerns on timber legality and forest-based livelihoods. For. Policy Econ. 2013, 32, 1-5.

78. Wenger, E. Communities of practice. A brief introduction. Available online: http://wengertrayner.com/wp-content/uploads/2013/10/06-Brief-introduction-to-communities-of-practice.pdf (accessed on 24 October 2014).

79. Bormann, B.T.; Haynes, R.W.; Martin, J.R. Adaptive management of forest ecosystems: Did some rubber hit the road? BioScience 2007, 57,186-191.

80. Derkyi, M.; Ros-Tonen, M.A.F.; Kyereh, B.; Dietz, T. Fighting over forest: Toward a shared analysis of livelihood conflicts and conflict management in Ghana. Soc. Natur. Resour. 2013, 3, 281-298.

81. Yasmi, Y.; Kelley, L.; Enters, T. Forest Conflict in Asia and the Role of Collective Action in Its Management; CAPRI Working Paper No.102; International Food Policy Research Institute: Washington, DC, USA, 2011.

82. Conference Organizing Committee. The Kumasi Resolution 2014. Presented at the First National Forestry Conference, The Contribution of Forests to Ghana's Economic Development, Kumasi, Ghana, 16-18 September 2014.

(C) 2014 by the authors; licensee MDPI, Basel, Switzerland. This article is an open access article distributed under the terms and conditions of the Creative Commons Attribution license (http://creativecommons.org/licenses/by/4.0/). 